\title{
The role of Institutions in explaining wage determination in the Euro Area: a panel cointegration approach
}

\author{
Mariam Camarero ${ }^{a}$, Gaetano D’Adamo ${ }^{\text {* }}$, Cecilio Tamarit ${ }^{b}$ \\ a Department of Economics, University Jaume I. Campus de Riu Sec E-12071 Castellón de la \\ Plana, Spain. \\ b Department of Applied Economics II, University of Valencia. Av.da dels Tarongers s/n 46022 \\ Valencia, Spain.
}

\begin{abstract}
$\underline{\text { Abstract }}$
Over the last 15 years, the evolution of labor costs has been very diverse across EMU countries. Since wages have important second-round effects on prices and competitiveness, and EMU countries do not have the tool of the nominal exchange rate to correct for such imbalances, understanding the determinants of the wage is a matter of increasing concern and debate. We estimate the equilibrium wage equation for the Euro Area over the period 1995-2011 using panel cointegration techniques that allow for cross-section dependence and structural breaks. The results show that the equilibrium wage has a positive relation with productivity and negative relation with unemployment, as expected. We also include institutional variables in our analysis, showing that a more flexible labor market is consistent with long-run wage moderation. Allowing for a regime break, we find that, since 2004, possibly due to increased international competition, wage determination was more strictly related to productivity, and real wage appreciation triggers a drop in the real wage. Furthermore, results point to a wage-moderating role of government intervention and concertation in wage bargaining.
\end{abstract}

JEL Classification: E24; J31; C23

Keywords: panel cointegration, wage setting, labor market.

\footnotetext{
*Corresponding author. Phone no.: (+34) 9638 28937. E-mail addresses: gaetano.dadamo@uv.es (G. D’Adamo); camarero@eco.uji.es (M. Camarero); cecilio.tamarit@uv.es (C. Tamarit).
} 


\section{Introduction}

The wage equation is a crucial element of any comprehensive model of the macroeconomy. A large strand of literature, since Blanchflower and Oswald (1994), has estimated the relationship between wages and unemployment $a$ la Phillips (1958), and more generally the equilibrium equation for the real wage. ${ }^{1}$

In the present paper, we use empirical techniques recently introduced by the literature to provide an estimation of the long-run equilibrium wage equation for the Euro Area, also taking into account the role of labor market institutions.

As shown in Figure 1, over the last 15 years the evolution of the real wage across EMU countries has been very diverse; these differences, in turn, were reflected in aggregate unit labor costs. On the one hand, wage setting has important secondround effects on prices and, therefore, potentially on competitiveness: when a country records persistently high inflation - for example due to increasing unit labor costs - with respect to the other member states of the Monetary Union, it will experience real exchange rate appreciation and a progressive loss of competitiveness. On the other hand, EMU countries cannot use the tool of the nominal exchange rate to correct divergent price dynamics. For this reason, the only way to correct such inflation differential in absence of nominal exchange rate depreciation is via internal devaluation.

Understanding how wage determination works in the euro area is therefore a matter of primary concern, also given the emphasis that the OECD first (OECD, 2004) and the European Commission especially in more recent years have been putting on labor market reforms and wage flexibility. At the same time, since EMU countries are also characterized by quite different labor market institutions, it is reasonable to think that the institutional framework, together with macroeconomic developments, has an important impact on wages.

Against this background, our paper studies the long-run determinants of real wages for EMU-11 countries, with a focus on labor market institutions. We extend a classic wage equation (Blanchard, 2000) to take into account the role of labor market regulation and wage bargaining. Thus, one important contribution of this paper is that it is the first work estimating equilibrium wage equations using cointegration that also accounts, in the long-run estimation, for institutional factors. Including institutional variables in the cointegration relation implies assuming that changes in the institutional set-up, for example a reform that increases the flexibility of the labor market, have permanent effects on the level of the real wage.

\footnotetext{
${ }^{1}$ To name but a few, Nunziata (2005), Broersma et al. (2005), Marcellino and Mizon (2000), Alesina and Perotti (1997), Baltagi et al. (2000).
} 
However, the main innovative feature of our analysis comes from the statistical design. We estimate the determinants of real wages using panel cointegration techniques that take into account the issue of cross-section dependence in the data and the presence of breaks in the series as well as in the cointegration relations. The issue of cross-section dependence is crucial when using macro data, especially for countries that are so much interlinked as EMU or OECD countries. Thus, we begin by testing for cross-section dependence using Pesaran's (2004) CD test and for the presence of a unit root in the data using the panel unit root tests CADF proposed by Pesaran (2007) and PANIC (Bai and Ng, 2004), which allow for such dependence. Moreover, we test for cointegration between the variables using panel cointegration tests which allow for an (unknown) break in the equilibrium relations, in particular the ones proposed by Banerjee and Carrión-i-Silvestre (2013). This is extremely important, considering the institutional changes national labor market in the Euro Area have been going through during the last 20 years, not to mention the introduction of the euro. We also efficiently estimate the longrun relationship (i.e. the wage equation) using the CUP-BC and CUP-FM estimators proposed in Bai et al. (2009), which correct for serial correlation and endogeneity.

The paper is organized as follows: section 2 reviews the literature on wage outcomes and labor market institutions; section 3 presents a stylized theoretical background; section 3 introduces the data used in the empirical analysis. Section 4 presents the panel unit root and cointegration tests performed and their results and section 5 reports the results of the panel estimation of the long-run relationship. Section 6 concludes.

\section{Literature review}

As we pointed out in the introduction, since the seminal work by Phillips (1958), the empirical literature has widely studied the relationship between unemployment and wages. Perhaps Sargan (1964) was the first one to interpret the Phillips curve as an adjustment mechanism around a long-run equilibrium relationship between the level of the wage and the unemployment rate.

Nevertheless, while the relationship between unemployment and labor market institutions (LMI) has been largely investigated over the last couple of decades (see Nickell 1997, Belot and Van Ours 2000, Nickell et al. 2005, among others), less empirical work has been dedicated to the relationship between LMIs and wages. However, as pointed out by Nunziata (2005), if labor market institutions affect unemployment it must be so via their impact on the cost of labor.

In their seminal work, Calmfors and Driffill (1988) suggested that the relationship between wage bargaining coordination and the real wage is nonlinear. In particular, both firm-level bargaining and economy-wide bargaining are associated with wage restraining, while intermediate (i.e. industry-level) bargaining is 
associated with a higher equilibrium wage. Evidence in support of the CalmforsDriffill hypothesis was found, among others, by Nunziata (2005). He studies the determinants of labor costs in OECD countries over the period 1960-1994 including a large vector of LMIs, finding that a more rigid labor market is associated with higher wages. Indeed, his work is similar in spirit to ours, although we focus on a different sample period and adopt a different empirical approach, estimating a "wage curve" à la Blanchflower and Oswald (1994).

Other works focused more specifically on the effects of taxation on wages. For example, Alesina and Perotti (1997) find that the relationship between the tax wedge and wages is hump-shaped and, with highly centralized bargaining, unions internalize the benefits for welfare associated with tax increases, especially if the government is involved in the bargaining process, and thus moderate their wage claims.

Nevertheless, the impact of labor market and wage bargaining institutions on the aggregate wage may change, at least to some extent, depending on the level of international competition and, therefore, the degree of openness of an economy. Egger and Etzel (2012) showed with a theoretical model that, while firms in more productive industries (and, thus, countries) pay higher wages, exporting lowers per worker profits because mark-ups on foreign markets are smaller. Thus, unions are more cautious about the negative effects of wage rises on employment and moderate their wage claims. These theoretical predictions are confirmed by Felbermayr et al. (2014), who find that a surge in the export intensity of collective bargaining plants is negatively correlated with wages.

Arpaia and Pichelmann (2007) study (nominal and real) wage flexibility in the EMU-12 between 1980 and 2005, finding that persistent differences in the evolution of labor costs and wage determination have prevented the necessary adjustment. They estimate the elasticity of the wage to unemployment to be around 0.3 , i.e. an increase in unemployment of 1 p.p. is associated with a fall in the real wage of $0.3 \%$. However, while they extensively discuss cross-country differences especially as far as wage rigidity is concerned, they do not attempt at accounting for the role of labor market institution, which are central to the present paper.

\section{Theoretical background}

In this section, we present a very stylized model of wage determination. We can interpret the observed real wage as the result of the bargaining process between employees' unions and employers. On the labor supply side, employees' unions tend to push for wage increases above productivity; however, their bargaining 
power depends on the unemployment rate since wage demands by unions tend to be more moderate when unemployment is high. Thus, we can write

$$
r_{-} \operatorname{comp}_{t}^{S}=f\left(\operatorname{prod}_{t}, \text { unemp }_{t}\right) ; f_{\text {prod }}^{\prime}>0, f_{\text {unemp }}^{\prime}<0
$$

where $r_{-} c o m p p_{t}^{S}$ is the (log) real wage on the labor supply side, measured as real compensation per hour worked; $\operatorname{prod}_{t}$ is (log) labor productivity and $u_{n e m p}$ is the unemployment rate. The existence of a positive, but less than proportional, relationship between the level of the real wage and productivity, on one hand, and a negative relationship between the unemployment rate and the real wage is, indeed, what is implied by Blanchflower and Oswald's (1994) "wage curve" as well as matching models (see Blanchard and Katz, 1997).

On the labor demand side, employers tend to constrain the real wage, maximizing their mark-up on unit labor costs, where the latter are defined as $r_{-} c o m p_{t}^{d}-$ $\operatorname{prod}_{t}$. The mark-up that employers will be able to extract from the real wage will, in turn, be related to the real exchange rate, which can proxy the competitive pressure that national producers face on international goods markets. The real exchange rate can affect labor costs in different ways. First, a fall in the real exchange rate (i.e. depreciation) increases the demand for domestic goods, thus raising labor demand and the real wage (Campa and Goldberg 2001). We will call this channel the labor demand channel. Second, when the real exchange rate decreases, increasing the cost of imported final goods, induces workers to attempt to maintain their real net incomes, increasing wage pressure (employees' pressure channel; Nunziata, 2005) ${ }^{2}$. Third, depreciation increases the price of imported intermediate goods and thus production costs; to the extent that those goods are complement to labor, it will foster a reduction in labor demand and in the real wage (imported intermediate goods channel; Robertson, 2003). Fourth, depreciation of the real exchange rate implies that imported goods are more expensive, which makes the consumer price index increase and real wage decline (imported inflation channel). If we define the real effective exchange rate as units of (trade-weighted) foreign goods per unit of domestic goods, the first and second channel would imply a negative relationship between $r_{-} \operatorname{comp}_{t}$ and the real exchange rate, while the third and fourth would imply a positive relationship. On the demand side, we can therefore write

$$
r_{-} \operatorname{comp}_{t}^{d}=g\left(\operatorname{prod}_{t}, \text { reer }_{t}\right)
$$

Where $g_{\text {prod }}^{\prime}>0$; reer $_{t}$ is the real exchange rate and therefore $g_{\text {reer }}^{\prime} \gtrless 0$ depending on which of the channels described above prevails.

Finally, the observed equilibrium wage is the result of additional wage pressure factors, which can be more generally classified as wage setting institutions. In

\footnotetext{
2 Due to asymmetric behavior of employee following a fall or an increase in the real exchange rate,
} this channel is likely to be relevant only when the reer depreciates. 
particular, a more flexible labor market should be associated with wage restraint: by increasing the bargaining power of insiders, higher employment protection may put upward pressure on bargained wages. However, previous literature that estimated the effect of employment protection has been focusing more on its impact on employment than wages. Moreover, other institutional factors such as the degree of coordination in wage bargaining and the involvement of unions in government decisions also affect the equilibrium wage ${ }^{3}$.

Therefore, combining the labor supply and demand side and in analogy with existing work (Nickell, 1998; Bell et al. 2002; Nunziata 2005), the long-run equilibrium wage equation can be written as a reduced-form specification suitable for estimation, incorporating both demand- and supply-side factors as well as institutional factors which may have an impact on the wage:

$$
r_{-} \operatorname{comp}_{t}=\beta_{0}+\beta_{1} \operatorname{prod}_{t}+\beta_{2} \text { unemp }_{t}+\beta_{3} \text { reer }_{t}+\boldsymbol{\beta}_{\mathbf{4}}{ }^{\prime} \boldsymbol{Z}_{\boldsymbol{t}}+\boldsymbol{\beta}_{\mathbf{5}}{ }^{\prime} \boldsymbol{X}_{\boldsymbol{t}}+\varepsilon_{t}
$$

Where we expect, a priori, $\beta_{1}>0, \beta_{2}<0$ and $\beta_{3} \gtrless 0 ; \boldsymbol{Z}_{\boldsymbol{t}}$ is a vector of variables defining government policy actions that might affect the level of the wage and $\boldsymbol{X}_{\boldsymbol{t}}$ is a vector of labor market institutions. While it is likely the case that reer is endogenous in (3), our empirical approach in Section 5 will take this issue into account.

In the empirical analysis, we will have that

$$
\boldsymbol{\beta}_{4}^{\prime} \boldsymbol{Z}_{\boldsymbol{t}}=\gamma_{1} d E A_{t}+\gamma_{2} G O V I N_{t}+\gamma_{3} T W E D_{t}+\gamma_{4} R I_{t}
$$

Where $d E A$ is a "euro adoption" dummy, GOVIN represents government intervention in wage bargaining, TWED is the tax wedge and $R I$ (routine involvement of unions and employers in policy decisions) is the degree of concertation. If euro adoption has fostered an increase in real wages, for example due to convergence of countries with lower initial wages like Spain, Portugal and Italy, to countries with higher initial wages, we should expect $\gamma_{1} \geq 0^{4}$. Government intervention may enhance wage moderation if the Government, acting as a social planner, is concerned about wage competitiveness. In this case, all else equal, a country with higher government intervention would have lower real wages. This is the case, for example, of the Netherlands, as pointed out by Borghans and Kriechel (2009). Therefore, we should expect $\gamma_{2} \leq 0$. Since we use net wages, the level of direct and indirect taxes, as well as social contributions, should ceteris paribus decrease the worker's wage, $\gamma_{3} \leq 0$. Regarding the involvement of unions in

\footnotetext{
${ }^{3}$ See Calmfors and Driffill (1988), Nunziata (2005), Boeri et al. (2001), among others.

4 The rationale for expecting $\gamma_{1} \geq 0$ is that a common currency makes comparison of nominal variables (i.e. prices and wages) easier. Therefore, as in inter-sectoral wage linkages models, workers in low-wage countries might push for higher wages due to social comparison and envy effects (Oswald 1979) or through the labor supply channel, moving where wages are higher (Demekas and Kontolemis 2000).
} 
bargaining, from our discussion in section 2 we expect that $\gamma_{4} \leq 0$ under high international competition.

As far as labor market institutions are concerned, we have

$$
\boldsymbol{\beta}_{5}^{\prime} \boldsymbol{X}_{t}=\delta_{1} W C O O R_{t}+\delta_{2} E P L_{t}+\delta_{3} U D_{t}+\delta_{4} M W S_{t}
$$

Where $W C O O R D_{t}$ is the degree of wage coordination (a higher $W C O O R D_{t}$ implies stronger coordination), $E P L_{t}$ represents the degree of employment protection, $U D_{t}$ is union density (i.e. the ratio of total union members to salaried employees) ${ }^{5}$, and $M W S$ represents the minimum wage.

According to the Calmfors and Driffill (1988) hypothesis, the relationship between centralization in wage bargaining (i.e. $W C O O R_{t}$ ) and the aggregate wage is not linear. In particular, with dominant firm-level bargaining, wage claims have a direct effect on the firm's competitiveness, and this will have a moderating effect on the unions' claims. However, at the same time, with economy-level bargaining and thus maximum co-ordination in wage bargaining, unions will internalize the cost of excessive wage claims and this will have a moderating effect on the wage. For this reason, the relationship between $W C O O R_{t}$ and the real wage should have an inverted-U shape. Our specification will not allow us to test for the Calmfors and Driffill (1988) hypothesis; however, the expected sign of $\delta_{1}$ depends on such hypothesis. In fact, since $W C O O R D$ in our data may take values from 1 (dominant firm-level bargaining) to 5 (dominant economy-wide bargaining) ${ }^{6}$ we can graphically represent the relationship between $W C O O R$ and the real wage suggested by the Calmfors-Driffill hypothesis as in Figure 2. Therefore, depending on whether the dominant level of wage bargaining within our sample is firm level (i.e. $W C O O R<3$ ) or national level $(W C O O R>3)$, $\delta_{1}$ will be positive or negative. Within our dataset, in all countries except France (also Ireland and Portugal, but for a very short period) WCOOR has always taken values between 3 and 5 . Therefore, we are in the right-hand side of Calmfors and Driffill's inverted-U curve. Based on this discussion, we would therefore expect $\delta_{1} \leq 0$. As far as $E P L_{t}$ is concerned, instead, from the previous discussion we should expect stricter employment protection to result in higher wages, ceteris paribus and thus $\delta_{2}>0$. Since higher Union Density increases unions' bargaining power, it is often assumed that $\delta_{3}>0$. However, this does not necessarily translate into higher wages. In fact, as discussed by Checchi and Nunziata (2011), national union leaders may internalize the effect of excessive wage pressure, and especially so when centralization is high, as it is the case in EMU-11 countries. In this sense, higher

\footnotetext{
${ }^{5}$ We use Union Density in place of bargaining coverage. We aware that bargaining coverage is the variable that affects real wage determination in the long-run; in fact, with higher coverage, wage increases are extended to a bigger pool of workers. However, UD is also a proxy of Unions' strength: the rationale is that we would expect Unions' bargaining power to be stronger if they represent a higher share of workers. Moreover, available data on bargaining coverage are of poorer quality.

${ }^{6}$ See Appendix 1 for details.
} 
Union Density may trigger wage moderation and $\delta_{3}<0$. We will come back to this point in Section 6.

Finally, as it is robustly found in the literature, we expect that the higher the minimum wage (or, the wider the coverage of minimum wage setting across sectors), the higher the aggregate wage, i.e. $\delta_{4}>0$.

\section{The Data}

We use quarterly data from 1995Q1 until 2011Q4 on the group of countries generally referred to as EMU-11: Austria, Belgium, Finland, France, Germany, Ireland, Italy, Luxembourg, Netherlands, Portugal and Spain ${ }^{7}$. Macroeconomic data comes from Eurostat and the variables are all seasonally and working day adjusted. The wage is defined as employees' compensation per worker, and is therefore calculated as the (log) difference of total compensation and number of persons employed:

$$
c o m p \_p=\ln \left(c o m p \_e m p\right)-\ln \left(e m p \_p\right)
$$

Productivity is calculated as output per worker, and therefore is the difference between the log of GDP and the log of persons employed.

Institutional variables come from J. Visser's ICTWSS database and the OECD ${ }^{8}$. The ICTWSS database provides annual data on 34 countries (all our countries are included in the database) about trade unionism, wage setting, state intervention and social pacts from 1960 to 2012 .

Remember, from equation (3), that we have two groups of institutional variables: government policy and labor market institutions.

There are four "Government policy" variables: $d E A, T W E D$, GOVIN and RI. $d E A$ is a dummy indicating euro adoption (i.e. taking a value of 1 since 1999Q1, and zero before that). TWED, the tax wedge, includes taxes and social contributions (net of subsidies) that create a wedge between the wage cost for the employer and what is actually earned by the employee. GOVIN is an index variable indicating government intervention in wage bargaining: it goes from 1 (the government does not intervene in wage bargaining) to 5 when the government imposes private sector wage settlements. $R I$ is routine involvement of employers and unions in wage bargaining, i.e. it represents the "concertation system". It is equal to zero when no concertation is present, up to 2 in the case of full concertation.

\footnotetext{
${ }^{7}$ The other current member states of the EMU were excluded due to lack of data on a quarterly basis, or because the available time series were too short.

${ }^{8} \mathrm{EPL}$ is not available for Luxembourg, which was therefore excluded from the institutional analysis.
} 
Furthermore, we include five variables describing the institutional setting of the labor market: WCOOR, EPL, UD and MWS. WCOOR is a discrete variable going from 1 (full decentralization, i.e. firm-level bargaining) to 5 (full coordination, i.e. economy-wide bargaining). EPL indicates the degree of employment protection. This variable goes from 0 to 5 and is constructed by the OECD using several indicators of labor market rigidity. In the current edition (2013) the OECD only provides separate indicators for temporary and permanent contracts. Therefore, following the guidelines of the previous (2009) edition, we reconstructed the overall indicator as an unweighted average of employment protection of permanent and temporary workers. $U D$, i.e. union density, is the share of employees who are members of a union. Finally, $M W S$ is a discrete variable indicating minimum wage setting: it is equal to 0 when there is no national minimum wage, to 8 when the minimum wage is set by the government (i.e. the minimum wage covers all sectors and is not a result of bargaining among employers and employees). Other works that estimate a wage equation, for example Nunziata (2005), actually use a measure of the minimum wage relative to the median (or average) aggregate wage, finding a positive impact of the minimum wage on the aggregate wage. However, some of the countries in our sample do not have a minimum wage, or did not have one over some of the sample period, which would significantly reduce our sample size. For this reason, we choose to look at the effect of the minimum wage from a different angle.

Note that, since both ICTWSS and OECD institutional data are annual, we had to transform them to quarterly: to that end, we used quadratic interpolation for $U D$ and $T W E D$; for the other institutional variables, whenever a change in the annual series was present, we looked for a corresponding reform or regulatory intervention within the year and thus constructed the quarterly series: dates of labor market reforms and collective agreements were taken from European Commission, Directorate General for Economic and Financial Affairs and Economic Policy Committee LABREF database.

Table 1 reports summary statistics of the variables involved. A detailed description of the variables and data sources is provided in Appendix 1.

\section{Panel Unit Root and Cointegration Tests}

We first applied Pesaran's (2004) cross-section dependence test (CD Test henceforth) to the variables. This test is formulated having as null hypothesis cross-section independence, so that its rejection would mean that dependence is found among the individual countries in the group and should be accounted for in 
the remaining panel tests. This is the case for the four variables in Table 2: the null hypothesis of independence is clearly rejected ${ }^{9}$.

Once we have found the presence of dependence in the variables, we have studied their order of integration using two different tests that account for dependence. Both are representative of the "second generation" panel unit root tests ${ }^{10}$.

First, we apply Pesaran's (2007) CADF test. In this case, unlike previous tests that demeaned the series to correct for the existence of dependence among the members of a panel, he augments the standard DF or ADF regressions with the cross-section averages of the lagged levels as well as the first differences of the individual series. Based on this procedure, he suggests developing modified versions of the t-bar test of Im et al. (2003) IPS test, the inverse chi-squared test (the P test) of Maddala and Wu (1999), and the inverse normal Z test suggested by Choi (2001). Pesaran (2007) defines the test statistics for the model with constant, with trend and with constant and trend. The main advantage of Pesaran's CADF test is that is simple and intuitive. Moreover, it is also valid for panels where $\mathrm{N}$ and $\mathrm{T}$ are of the same order of magnitude. This is frequently the case of panel unit roots applied to macro-variables.

Second, we also apply Bai and Ng (2004), a suitable approach when crosscorrelation is pervasive, as in this case. Furthermore, this approach controls for cross-section dependence given by cross-cointegration relationships, potentially possible among our group of countries and variables - see Banerjee et al. (2004). This is clearly the case for wages, but also for the real effective exchange rate.

Bai and Ng (2004) make use of residual factor models to take account of dependence. From a rather general set-up, they allow for the possibility of unit roots and cointegration in the common factors. However, they still assume that $\mathrm{N} / \mathrm{T} \rightarrow 0$, as $\mathrm{N}$ and $\mathrm{T} \rightarrow 1$. They apply the principal component procedure to the first-differenced version of the model. Then, they estimate the factor loadings as well as the first differences of the common factors.

They decompose $Y_{i, t}$, as follows:

$$
Y_{i, t}=D_{i, t}+F_{t}^{\prime} \pi_{i}+e_{i, t}
$$

with $\mathrm{t}=1, \ldots, T, \mathrm{i}=1, \ldots, N$, where $D_{i, t}$ denotes the deterministic part of the model - either a constant or a linear time trend $-F_{t}$ is a ( $\left.\mathrm{r} \times 1\right)$-vector that accounts for

\footnotetext{
9 The test was performed in Stata using the xtcd code provided by Markus Eberhardt in his webpage.

${ }^{10}$ See Breitung and Pesaran (2007) and Choi (2006) for a review of second-generation panel unit root tests.
} 
the common factors that are present in the panel, and $e_{i, t}$ is the idiosyncratic disturbance term, which is assumed to be cross-section independent. As stated above, unobserved common factors and idiosyncratic disturbance terms are estimated using principal components on the first difference model. For the estimated idiosyncratic component, they propose an ADF test for individual unit roots and a Fisher-type test for the pooled unit root hypothesis $\left(P_{\hat{e}}\right)$, which has a standard normal distribution. The estimation of the number of common factors is obtained using the panel BIC information criterion as suggested by Bai and $\mathrm{Ng}$ (2002), with a maximum of six common factors.

Bai and $\mathrm{Ng}$ (2004) propose several tests to select the number of independent stochastic trends, $k_{1}$ in the estimated common factors, $\hat{F}_{t}$. If a single common factor is estimated, they recommend an ADF test whereas if several common factors are obtained, they propose an iterative procedure to select $k_{1}$ : two modified $Q$ statistics $\left(M Q_{c}\right.$ and $\left.M Q_{f}\right)$, that use a non-parametric and a parametric correction respectively to account for additional serial correlation. Both statistics have a non-standard limiting distribution. The null hypothesis of $k_{1}=m$ is tested against the alternative $k_{1}<m$ for $m$ starting from $\hat{k}$. The procedure ends if at any step $k_{1}=m$ cannot be rejected.

The results of the Pesaran (2007) and Bai and Ng (2004) tests are presented Table $3^{11}$. The headings $\mathrm{CADF}(4)^{\mathrm{C}}$ and $\mathrm{CADF}(4)^{\mathrm{T}}$ correspond, respectively, to Pesaran's (2007) model with constant and with trend, where the number of lags chosen is $p=4$. The null hypothesis of unit root cannot be rejected for any of the variables analysed in the case of the model with constant. When the specification includes a trend, the unit root null is rejected for the real effective exchange rate. The righthand side of the table is devoted to the results of Bai and $\mathrm{Ng}$ (2004) panel unit root test. The number of chosen common factors is the maximum (six) for the two statistics and the first three variables. The exception this time is unemployment, where two factors are found in $\mathrm{MQ}_{\mathrm{c}}$ and three in $\mathrm{MQ}_{\mathrm{f}}$. Concerning the unit root tests, we find rejection in the idiosyncratic ADF test for the unemployment rate (at $5 \%$ ), whereas, according to the MQ tests all the common components are nonstationary.

Given our a priori theoretical expectations as exposed in section 2, we are looking for an equilibrium relationship between wages, productivity, the unemployment rate and the real (effective) exchange rate, which can then be augmented to include institutional variables as in equation (3).

Thus, the next step in our empirical strategy is to test for cointegration applying the Banerjee and Carrión-i-Silvestre (2013) test ${ }^{12}$. Using factor models to account

\footnotetext{
${ }^{11}$ The test was performed using Piotr Lewandowski's pescadf.ado Stata code.

${ }^{12}$ See Appendix 2 for a description of the specified models and the test.
} 
for cross-section dependence, they propose a panel test for the null hypothesis of no cointegration allowing for breaks both in the deterministic components and in the cointegrating vector. It is worth noticing that inference concerning the presence of cointegration can be affected by misspecification if the existence of breaks is ignored. They propose a test formulated for six different specifications of the deterministic components including a constant, a trend and structural breaks. They then recover the idiosyncratic disturbance terms $\left(\tilde{e}_{i t}\right)$ through accumulation of the estimated residuals and test for the null of no cointegration against the alternative of cointegration with breaks using the ADF statistic. In our case we concentrate in models with common homogenous structural breaks.

As shown in Table 4, using the Banerjee and Carrion (2013) to test for noncointegration, we apply the statistic based on the accumulated idiosyncratic components, $\mathrm{Z}_{\mathrm{j}}^{*}$. We present the test for all possible specifications; in all cases the null hypothesis of non-cointegration is rejected. Moreover, according to the information criteria ${ }^{13}$, the appropriate model could be either Model 3 (constant and trend restricted in the cointegration relation, and a break in both) or Model 6 (the break affects the level, the trend and the cointegrating vector, i.e. a "regime break"). The break is found to be in 2004Q2 in Model 3 and 2004Q4 using Model $6^{14}$. The Banerjee and Carrion (2013) test thus suggests that the preferred models include a trend in the cointegration relation. While including a linear term in the equilibrium relationship may be criticized since it is difficult to interpret economically, on the other hand it allows us to define the cointegration as one between the real wage and trend-adjusted productivity (plus other variables), where the trend proxies technological progress ${ }^{15}$.

\section{The wage equation of the EMU}

\subsection{A break in the constant and the trend}

Following the results of the Banerjee and Carrion-i-Silvestre (2013) test, we estimated equation (3) using the CUP-FM (continuously-updated and fullymodified) and CUP-BC (continuously-updated and bias-corrected) estimators (Bai et al., 2009) for the model with a break in the deterministic components (Model 3). These estimators present several advantages: they are valid when some or all of

\footnotetext{
${ }^{13}$ Using AIC we would have chosen Model 6, whereas according to BIC the best specification would be Model 3. Therefore, we present the results for both models. Moreover, the comparison between the two models is also interesting, as Model 8 allows for a structural change in the cointegrating relationship. The information criteria results are available from the authors upon request.

${ }^{14}$ We will discuss on the interpretation of this date in the following section.

15 Moreover, including a linear term is a standard procedure in cointegration analysis when the variables included seem to exhibit a deterministic trend, other tan a stochastic trend, and the slope of such trend is different across variables. In this case, excluding the trend from the cointegration relation may leave us with residual non-stationarity. See also Juselius (2006).
} 
the common factors are stationary, and also when some of the regressors are stationary; moreover, they are consistent since they correct for serial correlation and endogeneity, which is likely to be present in (3).

The results are reported in Table 5 and 6 for equation (2), using a specification without and with institutional variables, respectively.

First of all, let us consider Table 5, where the results of the cointegration analysis of the base wage equation, i.e. including macroeconomic variables prod, unemp and reer only, are reported. All coefficients have the expected sign (and magnitude) and are significant at all significance levels. In particular, the coefficient of prod is positive and lower than 1, i.e. productivity increases have a positive effect on the wage in the long run, but less than proportional. Unemployment has a negative relationship in the long run with the real wage. Interestingly, the estimated long-run elasticity of the real wage to unemployment is close to that estimated by Arpaia and Pichelmann (2007). Finally, the coefficient for reer is positive and significant: an increase in the real exchange rate fosters an increase in the real wage, thus the "imported inflation channel" and the "imported intermediate goods channel" indicated in section 3 prevail over the "labor demand" and the "employees' pressure" channel.

We then have included institutional variables in our cointegration analysis, and the results of the estimation are reported in Table 6.

We adopt a general-to-specific approach: in Table 6, we first estimate the model including all institutional variables. Then, we eliminate the coefficients with the lowest t-values one at a time as long as they were not significant with neither of the estimators. In particular, we estimate the models including, alternatively, (i) $W C O O R$ and (ii) $U D$, because the two variables appear to be collinear. More precisely, the impact of unions' bargaining power on wages is likely to be compensated by coordination. ${ }^{16}$

In the first two columns of Table 6, we report the results of the full specification. Since the tax wedge, EPL and $R I$ do not affect the long-run real wage in a significant way, we removed them from the model and we report the results of the estimation with selected variables in the last two columns of Table 6.

In all cases, the previous results on productivity, unemployment and the real exchange rate found in Table 5 are confirmed, although the coefficient of productivity is not always significant in (ii).

Interestingly, we find a positive and significant coefficient to euro adoption: according to our model, the adoption of the euro made the real aggregate wage increase by $3-5 \%$ depending on the specification. This might be due, for example,

${ }^{16}$ See Nunziata (2005), Nickell and Layard (1999) and Boeri, Brugiavini and Calmfors (2001). 
to a catch-up in the nominal wages in lower-wage countries (Portugal, Spain and Italy) to those of the "core" of the EMU.

All institutional variables have the expected sign: GOVINT has a negative and significant coefficient, supporting the idea that a government acting as a social planner (concerned about wage competitiveness) might foster wage moderation; a wider or more centralized system for minimum wages increases the equilibrium real wage (the coefficient of $M W S$ is positive and significant), while higher coordination in wage bargaining (higher WCOOR) is associated with a lower longrun real wage, given that the coefficient is negative. This confirms again our prior expectation of being "located" in the right-hand side of Calmfors and Driffill's inverted-U curve. In this sense, higher centralization of wage bargaining would bring about a drop in real wages.

Union Density $(U D)$ deserves a specific comment. The variable presents a long-run negative coefficient. This goes against what the a priori expectation suggesting that the relationship should be positive: the higher Union Density, the higher the bargaining power of unions and therefore the aggregate wage. On the other hand, this confirms the opposite view that Union leaders may internalize the cost of excessive wage increases, as discussed in section 2 and suggested by Checchi and Nunziata (2011). In this sense, above a certain threshold of union density, an increase in it may trigger wage moderation, a result which is consistent with Checchi and Lucifora's (2002) "good" view of unions, i.e. of unions being welfareenhancing. Note, moreover, that when $U D$ is included in place of WCOOR the coefficient of unemp drops. This might be due to the fact that, as suggested by Booth (1984), if unions are able to obtain preferential treatment for their members, and workers are heterogeneous in terms of risk aversion, other things equal an increase in aggregate unemployment risk raises union density (Booth 1984): thus, there might be a positive relationship between $U D$ and unemp. ${ }^{17}$

\subsection{A structural break}

The Banerjee and Carrion (2013) test performed in section 4 suggested that a structural break might be present in our relationship. Therefore, we proceed with the estimation of the wage equation including a change in long-run coefficient at the suggested date, 2004Q4. If a regime change is present, our estimates in Tables 5 and 6 would be inconsistent because we are simply averaging across two regimes. Table 7 reports the results of the estimation of the base model with a structural break. Indeed, the story is quite different with respect to Table 5. Note that, since the break is represented by a dummy that is equal to one from 2004Q4

\footnotetext{
17 Nevertheless, there is not a problem of multicollinearity here. Note that the literature on the determinants of union membership is, however, unsettled on the relationship between $U D$ and unemp. An alternative view suggests that, with high unemployment, unions are less able to influence firms' layoff decisions and therefore the incentive to join them is weaker (Boeri et al. 2001)
} 
onwards, which is then interacted with all the model variables, the value of the long-run coefficient of variable $X$ after the break is given by the sum of the coefficients on $X$ and $d 0404 * X$.

While we still have coefficients with the expected sign, we find that (i) the impact of productivity on the long-run real wage before 2004 was lower or even not significant, and it became clearly positive and significant afterwards; (ii) as far as the real exchange rate is concerned, a negative sign prevails since 2004: therefore, the "labor demand" and "employee pressure" channel dominated the others. In this sense, since 2004, wages appear to have been more sensitive to competitiveness changes due to real appreciation/depreciation, since a real appreciation triggered a drop in the long-run wage. We will come back to this point towards the end of the section.

In Table 8, we show the results of the estimation of the wage equation with institutional variables including a structural break. Previous results (Table 7) for productivity, unemployment and the real exchange rate are confirmed. Also the dummy "euro adoption" has the same value as in Table 5, and is significant. Looking at the coefficients of institutional variables, we find now a significant role of EPL: employment protection has a positive long-run effect on wages, as we would expect, although only in the second half of the sample, as well as TWEDGE with the expected negative sign. Moreover, our estimates suggest a stronger impact of MWS and after the break (the coefficient of $M W S \times d 0404$ is significant and positive). While government intervention has been wage restraining in the first part of the sample, after the break it is likely to have become insignificant. Interestingly, instead, concertation, that is, involvement of unions in economic policy decisions, which was pushing wages up in the first half of the sample, was wage-restraining after the break.

These results are very interesting because they all seem to point to the same direction. First of all, it is honestly difficult to interpret the 2004 break simply as far as the labor market is concerned. Indeed, the year was characterized by the Eastern enlargement of the EU, which was then completed in 2007 with the accession of Romania and Bulgaria. This supposedly brought about two shocks, on the goods production side and on the labor supply side. On one hand, firms in the Euro Area-11 (and, more generally, in the European Union-15) found themselves with increased product market competition due to the removal of all barriers vis $\grave{a}$ vis Central and Eastern Europe (CEE), although most of the process of trade barriers removal had already been completed in the previous years. On the other hand, free labor mobility from the CEE countries affected labor supply.

At the same time, the degree of openness of EMU-11 economies has largely increased over the sample period. Figure 3 shows the degree of openness of EMU11 countries in the two subperiods we identified, and it is easy to see that in 2004- 
2012 it was considerably higher for all countries except Ireland (where it was almost unchanged). In the case of Germany, openness increased as much as $43 \%$, going from 59\% of GDP up to 84\%, With firms facing increased international competition, it is realistic to think that wage bargaining was less influenced by domestic factors like unions' bargaining power and labor market institutions, and therefore wage developments became more strictly linked to productivity developments (the coefficient on productivity became positive and significant), in an attempt to keep unit labor costs stable; this would explain a wage-moderating effect of concertation mechanisms as well as the change of sign of the coefficient of the real exchange rate, as discussed above.

\subsection{Robustness checks}

One might argue that, due to second-round effects of wages on prices, the wage affects the real exchange rate and competitiveness as well, and that therefore a problem of simultaneity between the real exchange rate and wages in our model may be present. While our empirical approach takes endogeneity into account, in this section we take a more radical approach by replacing reer with the nominal effective exchange rate, neer ${ }^{18}$. Indeed, in this respect, we acknowledge that what matters for competitiveness is not the nominal exchange rate, but rather the real exchange rate. However, due to price stickiness, movements in the real exchange rate in the short-medium run are driven by nominal exchange rate developments; plus, there is a quite strong positive correlation between the two variables within our sample (about 0.5). Finally, while nominal exchange rate developments, affecting the real exchange rate, may in principle affect the real wage, it can hardly be argued that the reverse is true. Therefore, as a robustness check to estimate the relationship between exchange rates and wages as discussed in Section 2, we use the nominal instead of the real effective exchange rate ${ }^{19}$.

The results of this robustness check are reported in Table 9, for the model with no institutional variables and with selected institutional variables ${ }^{20}$. The robustness checks confirm our previous results, albeit with some slight differences. When we replace the real exchange rate with the nominal effective rate, all results discussed in 5.2 are confirmed. As far as the relationship between the exchange rate and the

\footnotetext{
18 The nominal effective exchange rate is the weighted average of nominal exchange rates with trade partners. Since countries in our sample share have irrevocably fixed the exchange rates with each other since 1998Q2, cross-country differences in the evolution of the neer will only be due to differences in the shares of international trade of their trade partners, and how the euro exchange rate with those trade partners have evolved. Indeed, the cross-country correlation is quite high, although it ranges from 0.70 (Italy/Luxembourg) to 0.99 (Belgium/Netherlands). Nevertheless, our approach takes cross-sectional dependence into account.

${ }^{19}$ As in Section 4 above, we first performed the cross-section dependence CD test and the PANIC unit root test on neer. We rejected cross-section independence at all significance levels with the former, while we could not reject the existence of a unit root with the latter. Detailed results are available upon request.

${ }^{20}$ We only report, for brevity, the results using Model 6 (Structural break).
} 
wage is concerned, it is negative throughout the sample; however, the "wagerestraining" role of the exchange rate becomes significantly stronger after 2004, thus confirming our results obtained in the initial model using the real exchange rate, and this result is confirmed both in the model including WCOOR and that including $U D$.

\section{Conclusions}

In this paper, we have estimated an equilibrium wage equation for the Euro Area over the period 1995-2011 using panel cointegration techniques which take into account the issue of cross-section dependence in the data and the presence of breaks in the series and in the cointegration relations. Moreover, we have also included institutional variables in the long-run equation, in order to show how a different design of the labor market, and government policies may be consistent with wage moderation.

The cointegration techniques adopted in the present work allowed us to include a break in the long-run relationships. The break was found to be in 2004 (second or fourth quarter, depending on the chosen model). While, on one hand, it does not seem possible to identify a specific event that triggered this break, on the other hand, the way that the wage equation was affected is very clear: increased labor market flexibility and increased international competition made the long-run real wage more productivity-determined; moreover, the wage tended to adjust to compensate for real exchange rate appreciations (i.e. it dropped when the real exchange rate was above equilibrium) and concertation mechanisms were wagemoderating. Finally, subsequent labor market reforms have restrained the real wage.

This last result confirms previous works similar to ours, suggesting that a more flexible labor market is consistent with wage moderation and, therefore, lower equilibrium unemployment.

We argued in section 6 that increased product competition coming from international trade, as well as higher international labor mobility, both presumably resulting from the 2004 EU eastern enlargement, may have a role in explaining this break, together with the rapid increase in the degree of trade openness of each of the Euro Area-11 countries, except Ireland, over the sample period. Indeed, the changes in the cointegration vector implied by the 2004 regime break, suggest that firms (and unions) became more concerned with the impact that real wage increases have on competitiveness.

Finally, our results have an additional, more general implication which is related to the Lucas (1976) critique: it is crucial to account for a break in the estimation of 
the long run real wage equation; failure to do so may reduce the power of cointegration tests, as discussed in the literature (see also Banerjee and Carrion-iSilvestre 2013), and it may also lead to a misinterpretation of the estimated coefficients, as our discussion has demonstrated.

\section{Acknowledgements}

The authors gratefully acknowledge the financial support from the MINECO projects EC02011-30260-C03-01, Generalitat Valenciana Prometeo action 2009/098 and the European Commission (Lifelong Learning Program-Jean Monnet Action references 542457-LLP-1-2013-1-ES-AJM-CL and 542434-LLP-1-2013-1ES-AJM-CL). We are thankful to participants to the IVth Workshop in Time Series Econometrics (Zaragoza, April 2-3 2014) for their enlightening comments and also thank Josep Lluís Carrion-i-Silvestre for providing us the computer codes to apply the Banerjee and Carrion (2013) test, as well as for giving us very valuable suggestions and advice. All the remaining errors are ours.

\section{References}

Arpaia, A., Pichelmann, K., 2007. Nominal and Real wage flexibility in the EMU. International Economics and Economic Policy 4(3), 299-328.

Bai, J., Ng, S., 2004. A Panic attack on Unit Rooots and Cointegration, Econometrica 72(4), 1127-1177.

Bai, J., Kao, C., Ng, S., 2009. Panel cointegration with global stochastic trends. Journal of Econometrics 149, 82-99.

Banerjee, A., Carrion-i-Silvestre, J.L., 2013. Cointegration in panel data with structural breaks and cross-section dependence. Forthcoming Journal of Applied Econometrics, DOI: 10.1002/jae.2348.

Bell, B., Nickell, S., Quintini, G., 2002. Wage equations, wage curves and all that. Labour Economics 9 (3), 341-360.

Belot, M., Van Ours, J.C., 2004. Does the recent success of some OECD countries in lowering their unemployment rates lie in the clever design of their labor market reforms? Oxford Economic Papers 56(4), 621-642.

Blanchard, O., Katz, L.F., 1999. Wage Dynamics: Reconciling Theory and Evidence. American Economic Review 89(2), 69-74.

Blanchard, 0., 2000. The Economics of Unemployment. Shocks, institutions and interactions. Lionel Robbins Lectures, London School of Economics.

Blanchflower, D.G., Oswald, A.J., 1994. The wage curve. MIT Press, Boston. 
Boeri, T., Brugiavini, A., Calmfors, L., 2001. The role of unions in the Twenty-first century - A report for the Fondazione Rodolfo Debenedetti, Oxford University Press, Oxford.

Booth, A., 1984. A public choice model of trade union behaviour and membership. Economic Journal 94, 883-98.

Borghans, L., Kriechel, B., 2009. Wage structure and labor mobility in the Netherlands, 1999-2003. In Lazear, E.P., Shaw K.L. (Eds.), The Structure of wages: an International Comparison. University of Chicago Press, Chicago.

Breitung J., Pesaran, M.H., 2007. Unit roots and cointegration in panels. In Mátyás L, Sevestre, P. (Eds.): The Econometrics of Panel Data: Fundamentals and Recent Developments in Theory and Practice. Kluwer, Dordrecht.

Calmfors, L., Driffill, J., 1988. Bargaining structure, corporatism, and macroeconomic performance. Economic Policy 6, 14-61.

Calmfors, L., Larsson, A., 2011. 2013. Pattern Bargaining and Wage Leadership in a Small Open Economy. Scandinavian Journal of Economics. 115(1), 109-140.

Campa, J. M., Goldberg, L. S. 2001. Employment Versus Wage Adjustment and the U.S. Dollar. The Review of Economics and Statistics 83(3), 477-89.

Checchi, D., Nunziata, L., 2011. Models of unionism and unemployment. European Journal of Industrial Relations 17(2), 141-152.

Choi, I., 2006. Nonstationary panels. In: Mills, T.C., Patterson, K. (Eds.), Palgrave Handbooks of Econometrics, vol. 1,. Palgrave Macmillan, Basingstoke, 511-539.

Demekas, D.G., Kontolemis, Z.G., 2000. Government employment and wages and labour market performance. Oxford Bulletin of Economics and Statistics 62(3), 391415.

Egger, H., Etzel, D., 2012. The Impact of Trade on Employment, Welfare, and Income Distribution in Unionized General Oligopolistic Equilibrium. European Economic Review 56, 1119-1135.

Felbermayr, G., Hauptmann, A., Schmerer, H.J., 2014. International Trade and Collective Bargaining Outcomes: Evidence from German Employer - Employee Data. The Scandinavian Journal of Economics 116(3), 820-837.

Lucas, R., 1976. Econometric Policy Evaluation: A Critique. In Brunner, K.; Meltzer, A. The Phillips Curve and Labor Markets. Carnegie-Rochester Conference Series on Public Policy 1. New York: American Elsevier. pp. 19-46.

Nickell, S.J., 1998. Unemployment: questions and some answers. The Economic Journal 108, 802-816. 
Nickell, S.J., LAYARD, R., 1999. Labour market institutions and economic performance. In: Ashenfelter, O. Layard, R. (Eds), Handbook of Labor Economics. North-Holland Press, Amsterdam.

Nunziata, L., 2005. Institutions and wage determination: a multi-country approach. Oxford Bulletin of Economics and Statistics 67(4), 435-466.

OECD (2004), OECD Employment Outlook. OECD, Paris.

Oswald, A.J., 1979. Wage determination in an economy with many trade unions. Oxford Economic Papers 31(3), 369-385.

Phelps, E. S., 1994. Structural Slumps. The modern equilibrium theory of unemployment, interest and assets. Harvard University Press, Cambridge MA.

Robertson, R., 2003. Exchange Rates and Relative Wages: Evidence from Mexico. North American Journal of Economics and Finance 14, 25-48.

Sargan, J.D., 1964. Wages and Prices in the United Kingdom: a study in econometric methodology. Reprinted in: Hendry, D.F., Wallis, K.F. (Eds.), 1984. Econometrics and Quantitative Economics. Basil Blackwell, Oxford.

Visser, J., 2011. ICTWSS: Database on Institutional Characteristics of Trade Unions, Wage Setting, State Intervention and Social Pacts in 34 countries. Version 3 - May 2011. Amsterdam Institute for Advanced Labour Studies, University of Amsterdam. 


\section{Appendix A. Series definition}

\begin{tabular}{|c|c|}
\hline unemp & unemployment rate. Source: Eurostat. \\
\hline comp_emp & total compensation of employees. Source: Eurostat. \\
\hline$e m p \_p$ & thousands of persons employed. Source: Eurostat. \\
\hline reer & ULC-deflated real effective exchange rate. Source: IFS. \\
\hline neer & Nominal Effective Exchange Rate. Source: Eurostat. \\
\hline WCOOR & $\begin{array}{l}\text { Coordination of wage bargaining. } 5 \text { : economy-wide bargaining; } 4 \text { : } \\
\text { mixed industry- and economy-wide; ... 1= company-level } \\
\text { bargaining. Source: ICTWSS Database. }\end{array}$ \\
\hline$E P L$ & $\begin{array}{l}\text { Employment Protection Legislation. } 0 \text { = minimum employment } \\
\text { protection; } 5 \text { = maximum employment protection. Source: OECD. }\end{array}$ \\
\hline$r_{-}$comp & real compensation per employee: \\
\hline & $\begin{array}{l}\ln \left(c o m p \_e m p\right)-\ln \left(e m p \_p\right)-\ln (C P I) \text {. CPI is seasonally adjusted } \\
\text { using TRAMO/SEATS, }\end{array}$ \\
\hline prod & labor productivity per worker: $\ln (g d p)-\ln \left(e m p \_p\right)$ \\
\hline$U D$ & union density (in \%). Source: ICTWSS Database. \\
\hline GOVIN & Government intervention in wage bargaining \\
\hline RI & $\begin{array}{l}\text { Routine involvement of unions and employers in government } \\
\text { decisions on social and economic policy. Discrete variable going } \\
\text { from } 0 \text { (no concertation) to } 1 \text { (partial/infrequent concertation) to } 2 \\
\text { (full, regular concertation). Source: ICTWSS Database. }\end{array}$ \\
\hline$M W S$ & $\begin{array}{l}\text { Minimum wage setting. } 0=\text { no minimum wage } . .8=\text { minimum wage } \\
\text { is set by government, with no fixed rule. Source: ICTWSS Database. }\end{array}$ \\
\hline TWED & $\begin{array}{l}\text { Tax wedge. Constructed as: (direct taxes/employees compensation) } \\
+ \text { (indirect taxes - subsidies)/private consumption expenditure + } \\
\text { (social security contributions)/(employees' compensation - social } \\
\text { security contributions). Source: AMECO, Eurostat and our } \\
\text { calculations. }\end{array}$ \\
\hline
\end{tabular}

\section{Appendix B - The Banerjee and Carrion (2013) Cointegration Test with breaks and dependence}

Banerjee and Carrion-i-Silvestre (2013) propose a panel test for the null hypothesis of no cointegration allowing for breaks both in the deterministic components and in the cointegrating vector, also accounting for the presence of cross-section dependence using factor models. They define a ( $m \times 1)$ vector of nonstationary stochastic process, $Y_{i t}=\left(y_{i t}, x_{i t}\right)$ whose elements are individually $I(1)$ with the following Data Generating Process:

$$
y_{i t}=D_{i t}+x^{\prime}{ }_{i t} \delta_{i t}+u_{i t}
$$


The general functional form for the deterministic term $D_{i t}$ is given by:

$$
D_{i t}=\mu_{i}+\beta_{i} t+\sum_{j=1}^{m_{i}} \theta_{i j} D U_{i j t}+\sum_{j=1}^{m_{i}} \gamma_{i j} D T_{i j t}
$$

Where $D U_{i j t}=1$ and $D T_{i j t}=\left(t-T_{i t}^{b}\right)$ for $t>T_{i t}^{b}$ and 0 otherwise, $T_{i t}^{b}=\lambda_{i j}^{b} T$ denotes the timing of the $j$-th break, $j=1, \ldots, m_{i}$, for the i-th unit, $i=1, \ldots, N, \lambda_{i j}^{b} T \in \Lambda$, being $\Lambda$ a closed subset of $(0,1)$. The cointegrating vector is a function of time so that

$$
\delta_{i t}=\left\{\begin{array}{c}
\delta_{i 1} T_{i 0}^{c}<t \leq T_{i 1}^{c} \\
\delta_{i 2} T_{i 1}^{c}<t \leq T_{i 2}^{c} \\
\delta_{i j} T_{i, j-1}^{c} \quad \cdots t \leq T_{i j}^{c} \\
\delta_{i n_{i}+1} T_{i n_{i}}^{c} \quad \stackrel{<}{<} \leq T_{i n_{i}+1}^{c}
\end{array}\right.
$$

with $T_{i 0}^{c}=0$ and $T_{i, n+1}^{c}=T$, where $T_{i j}^{c}=\lambda_{i j}^{c} T$ denoting the $j$-th time of the break, $j$ $=1, \ldots, n_{i}$, for the $i$-th unit, $i=1, \ldots, N$, for the $i$-th unit, $i=1, \ldots, N \lambda_{i j}^{c} \in \Lambda$.

Banerjee and Carrion-i-Silvestre (2013) propose six different model specifications:

Model 1., No linear trend $-\boldsymbol{\theta}_{\boldsymbol{i j}}=\boldsymbol{\beta}_{\boldsymbol{i}}=\gamma_{i, j}=\mathbf{0} \forall \boldsymbol{i}, \boldsymbol{j}$ in (A.2) - and stable cointegrating vector $-\delta_{i j}=\delta_{i} \forall j$ in [A.3].

Model 2. Stable trend $-\boldsymbol{\theta}_{i j}=\mathbf{0} ; \boldsymbol{\beta}_{\boldsymbol{i}} \neq \mathbf{0} \forall i$ and $\gamma_{i, j}=\mathbf{0} \forall \boldsymbol{i}, \boldsymbol{j}$ in (A.2) - and stable cointegrating vector $-\delta_{i j}=\delta_{i} \forall j$ in [A.3].

Model 3. Changes in level and trend - $\boldsymbol{\theta}_{\boldsymbol{i j}} \neq \mathbf{0} ; \boldsymbol{\beta}_{\boldsymbol{i}} \neq \boldsymbol{\gamma}_{\mathbf{i}, \boldsymbol{j}} \neq \mathbf{0} \forall \boldsymbol{i}, \boldsymbol{j}$ in (A.2) - and stable cointegrating vector $-\delta_{i j}=\delta_{i} \forall j$ in [A.3].

Model 4. No linear trend $-\boldsymbol{\beta}_{\boldsymbol{i}}=\gamma_{i, j}=\mathbf{0} \forall \boldsymbol{i}, \boldsymbol{j}$ in (A.2) but presence of multiple structural breaks that affect both the level and the cointegrating vector of the model.

Model 5. Stable trend $\boldsymbol{\beta}_{\boldsymbol{i}} \neq \mathbf{0} \forall i$ and $\gamma_{i, j}=\mathbf{0} \forall \boldsymbol{i}, \boldsymbol{j}$ in (A.2) with multiple structural breaks that affect both the level and the cointegrating vector of the model.

Model 6. Changes in the level, trend and in the cointegrating vector. No constraints are imposed on the parameters of equations (A.2) and (A.3).

The common factors are estimated following the method proposed by Bai and $\mathrm{Ng}$ (2004). They start by computing the first difference of the model; then, they take 
the orthogonal projections and estimate the common factors and the factor loadings using principal components.

In any of these specifications, Banerjee and Carrion-i-Silvestre (2013) recover the idiosyncratic disturbance terms $\left(\tilde{e}_{i t}\right)$ through accumulation of the estimated residuals and propose testing for the null of no cointegration against the alternative of cointegration with break using the ADF statistic.

The null hypothesis of a unit root can be tested using the pseudo $t$-ratio $t_{\tilde{e}}^{j}=\left(\lambda_{i}\right), j=c, \tau, \gamma$. The models that do not include a time trend (Models 1 and 4 ) are denoted by $c$. Those that include a linear time trend with stable trend (Models 2 , and 5) are denoted by $\tau$ and, finally, $\gamma$ refers to the models with a time trend with changing trend (Models 3 and 6). When common (homogeneous) structural breaks are imposed to all the units of the panel (although with different magnitudes), we can compute the statistic for the break dates, where the break dates are the same for each unit, using the idiosyncratic disturbance terms. 
TABLE 1

Summary Statistics

\begin{tabular}{cccc} 
& N.Obs. & mean & standard dev. \\
\hline comp_p & 739 & 2.945 & 0.817 \\
unemp & 748 & 0.077 & 0.035 \\
prod & 748 & 1.481 & 0.116 \\
reer & 748 & 0.987 & 0.052 \\
UD & 724 & 0.331 & 0.178 \\
EPL & 696 & 2.334 & 0.739 \\
WCOOR & 748 & 3.464 & 1.015 \\
MWS & 748 & 4.398 & 2.856 \\
GOVIN & 746 & 3.177 & 0.907 \\
TWED & 731 & 0.406 & 0.185 \\
$R I$ & 748 & 1.360 & 0.655 \\
\hline
\end{tabular}

TABLE 2

Pesaran's (2004) Cross-Section Dependence CD Test

\begin{tabular}{cll}
\hline & CD Test Statistic & P-value \\
\hline r_comp $_{i t}$ & 32.27 & 0.000 \\
reer $_{i t}$ & 34.19 & 0.000 \\
prod $_{i t}$ & 7.78 & 0.000 \\
unemp $_{i t}$ & 18.61 & 0.000 \\
\hline
\end{tabular}

Note: Null hypothesis states that series are cross-section independent. $C D \sim N(0,1)$ under $H_{0}$.

TABLE 3

Panel unit Root Tests

\begin{tabular}{clllllll}
\hline & CADF(4) $^{\mathbf{C}}$ & $\mathbf{C A D F ( 4 )}$ & $\mathbf{r}_{\mathbf{c}}$ & $\mathbf{M Q}_{\mathbf{c}}$ & $\mathbf{r}_{\mathbf{f}}$ & $\mathbf{M Q}_{\mathbf{f}}$ & $\begin{array}{l}\text { Idiosync. } \\
\mathbf{A D F}\end{array}$ \\
\hline$r_{-}$comp $_{i t}$ & $\begin{array}{l}0.497 \\
(0.690)\end{array}$ & $\begin{array}{l}3.163 \\
(0.999)\end{array}$ & 6 & -46.062 & 6 & -44.375 & $\begin{array}{l}0.867 \\
(0.807)\end{array}$ \\
\hline reer $_{i t}$ & $\begin{array}{l}-1.573 \\
(0.058)\end{array}$ & $\begin{array}{l}-2.390 \\
(0.008)\end{array}$ & 6 & -53.960 & 6 & -54.128 & $\begin{array}{l}0.353 \\
(0.638)\end{array}$ \\
\hline prod $_{i t}$ & $\begin{array}{l}0.065 \\
(0.526)\end{array}$ & $\begin{array}{l}3.692 \\
(1.000)\end{array}$ & 6 & -41.309 & 6 & -40.407 & $\begin{array}{l}1.008 \\
(0.843)\end{array}$ \\
\hline unemp $_{i t}$ & $\begin{array}{l}0.275 \\
(0.608)\end{array}$ & $\begin{array}{l}1.853 \\
(0.968)\end{array}$ & 6 & -46.841 & 6 & -48.955 & $\begin{array}{l}2.164 \\
(0.015)\end{array}$ \\
\hline
\end{tabular}

P-values in parenthesis. Critical Values for the MQ statistic are tabulated by Bai and $\mathrm{Ng}$ (2004), Table $I . r_{c}$ is the number of common factors in $M Q_{c} ; r_{f}$ is the number of common factors in $M Q_{f}$. The last column represents the unit root test on the idiosyncratic component as in Bai and $\mathrm{Ng}$ (2004). 
TABLE 4

Banerjee and Carrion (2013) panel cointegration tests

\begin{tabular}{llll}
\hline \multicolumn{4}{c}{\begin{tabular}{l}
\multicolumn{3}{l}{ f(prod $_{i j t}$ reer $_{i j t,}$} \\
unemp $\left._{i j t}\right)$
\end{tabular}} \\
\hline Model & $Z_{j}^{*}$ & AIC & BIC \\
\hline 1 & -6.85 & -8.71 & -8.55 \\
2 & -5.82 & -8.78 & -8.58 \\
3 & $\mathbf{- 4 . 7 2}$ & -8.96 & $\mathbf{- 8 . 6 7}$ \\
4 & -6.19 & -8.53 & -8.21 \\
5 & -5.41 & -8.68 & -8.31 \\
6 & $\mathbf{- 4 . 2 5}$ & $\mathbf{- 8 . 9 9}$ & -8.58 \\
\hline
\end{tabular}

Note: Critical values of the $Z_{j}^{*}$ are $-2.824,-2.113$ and -1.759 at $1 \%, 5 \%$ and $10 \%$ significance levels, respectively, for the model with constant, whereas $-2.924,-2.240$ and -1.835 are their equivalents in the model with trend.

\section{TABLE 5}

Estimation of the long run parameters - Base Long-Run Model

\begin{tabular}{cll} 
& CUP - FM & CUP - BC \\
\hline prod $_{i t}$ & $0.550^{* * *}(3.770)$ & $0.725^{* * *}(4.839)$ \\
reer $_{i t}$ & $0.322^{* * *}(7.890)$ & $0.313^{* * *}(7.716)$ \\
unemp $_{i t}$ & $-0.384^{* * *}(-4.446)$ & $-0.387^{* * *}(-4.480)$ \\
\hline
\end{tabular}

Absolute t-values in parenthesis. All models are estimated with 2 factors, as suggested by PCA. The bandwidth was chosen using Silverman's rule of thumb. ${ }^{* * *}$ : significant at $1 \%,{ }^{* *}$ : at $5 \%,{ }^{*}$ : at $10 \%$. 


\section{TABLE 6}

Estimation of the long run model including institutions

\begin{tabular}{|c|c|c|c|c|c|c|c|c|}
\hline & \multicolumn{2}{|c|}{ Full Specification (i) } & \multicolumn{2}{|c|}{ Full Specification (ii) } & \multicolumn{2}{|c|}{ Selected Variables (i) } & \multicolumn{2}{|c|}{ Selected Variables (ii) } \\
\hline & CUP - FM & CUP - BC & CUP - FM & CUP - BC & CUP - FM & CUP - BC & CUP - FM & CUP - BC \\
\hline \multirow[t]{2}{*}{$\operatorname{prod}_{i t}$} & $0.296^{* *}$ & $0.366^{* *}$ & 0.136 & 0.194 & $0.382^{* * *}$ & $0.477^{* * *}$ & 0.208 & $0.288^{*}$ \\
\hline & $(2.069)$ & $(2.534)$ & $(0.906)$ & $(1.273)$ & $(2.693)$ & $(3.346)$ & $(1.389)$ & $(1.898)$ \\
\hline \multirow[t]{2}{*}{$\operatorname{reer}_{i t}$} & $0.257^{* * *}$ & $0.228 * * *$ & $0.286^{* * *}$ & $0.279 * * *$ & $0.226^{* * *}$ & $0.223^{* * *}$ & $0.260 * * *$ & $0.280 * * *$ \\
\hline & $(5.744)$ & $(5.098)$ & $(6.394)$ & (6.237) & $(5.314)$ & $(5.234)$ & $(6.090)$ & $(6.557)$ \\
\hline \multirow{2}{*}{$u_{n e m p} p_{i t}$} & $-0.426^{* * *}$ & $-0.421^{* * *}$ & $-0.199 * *$ & $-0.172 * *$ & $-0.435^{* * *}$ & $-0.466^{* * *}$ & $-0.201^{* *}$ & $-0.207^{* *}$ \\
\hline & $(-4.810)$ & $(-4.750)$ & $(-2.275)$ & $(-1.961)$ & $(-4.912)$ & $(-5.262)$ & $(-2.305)$ & $(-2.372)$ \\
\hline \multirow[t]{2}{*}{$E A_{i t}$} & $0.044^{* * *}$ & $0.034^{* * *}$ & $0.054^{* *}$ & $0.047^{* * *}$ & $0.041^{* * *}$ & $0.028^{* * *}$ & $0.051^{* * *}$ & $0.041^{* * *}$ \\
\hline & $(4.857)$ & (3.681) & (5.986) & (5.175) & $(4.534)$ & $(3.062)$ & $(5.650)$ & $(4.551)$ \\
\hline \multirow[t]{2}{*}{$G O V I N_{i t}$} & $-0.009 * * *$ & $-0.009 * * *$ & $-0.011^{* * *}$ & $-0.012^{* * *}$ & $-0.008^{* * *}$ & $-0.007^{* * *}$ & $-0.011^{* * *}$ & $-0.011^{* * *}$ \\
\hline & $(-3.777)$ & $(-3.595)$ & $(-4.776)$ & $(-5.111)$ & $(3.445)$ & $(-3.004)$ & $(-4.752)$ & $(-4.663)$ \\
\hline \multirow[t]{2}{*}{$T W E D_{i t}$} & 0.029 & -0.009 & 0.025 & 0.007 & & & & \\
\hline & $(1.614)$ & $(0.496)$ & (1.398) & $(0.403)$ & & & & \\
\hline \multirow[t]{2}{*}{$R I_{i t}$} & 0.002 & 0.009 & 0.002 & 0.006 & & & & \\
\hline & $(0.438)$ & $(0.988)$ & $(0.363)$ & (1.128) & & & & \\
\hline \multirow[t]{2}{*}{$E P L_{i t}$} & 0.002 & 0.005 & 0.002 & 0.001 & & & & \\
\hline & $(0.949)$ & $(0.603)$ & $(0.835)$ & $(0.559)$ & & & & \\
\hline \multirow{2}{*}{$W C O O R_{i t}$} & $-0.014^{* * *}$ & $-0.015^{* * *}$ & & & $-0.014^{* * *}$ & $-0.015^{* * *}$ & & \\
\hline & $(-3.707)$ & $(-3.885)$ & & & $(-3.767)$ & $(-4.174)$ & & \\
\hline \multirow[t]{2}{*}{$U D_{i t}$} & & & $-0.061^{* * *}$ & $-0.047^{* *}$ & & & $-0.061^{* * *}$ & $-0.048^{* *}$ \\
\hline & & & $(-3.110)$ & $(-2.396)$ & & & $(-3.089)$ & $(-2.429)$ \\
\hline \multirow[t]{2}{*}{$M W S_{i t}$} & $0.007^{* * *}$ & $0.007^{* * *}$ & $0.008^{* * *}$ & $0.008^{* * *}$ & $0.008^{* * *}$ & $0.008^{* * *}$ & $0.008^{* * *}$ & $0.009 * * *$ \\
\hline & $(3.795)$ & $(3.849)$ & $(4.401)$ & $(4.064)$ & $(4.127)$ & $(4.336)$ & $(4.728)$ & $(4.603)$ \\
\hline
\end{tabular}

Absolute t-values in parenthesis. Models are estimated with 2 factors, as suggested by PCA. Bandwidth chosen using Silverman's rule of thumb. ${ }^{* * *}$ : significant at $1 \%,{ }^{* *}:$ at $5 \%,{ }^{*}:$ at $10 \%$. 
TABLE 7

Base long-run model - Structural break

\begin{tabular}{|c|c|c|}
\hline & CUP - FM & CUP - BC \\
\hline $\operatorname{prod}_{i t}$ & $0.204(1.442)$ & $0.249 *(1.736)$ \\
\hline reer $_{i t}$ & $0.391^{* * *}(8.841)$ & $0.394^{* * *}(8.925)$ \\
\hline unemp $_{i t}$ & $-0.580^{* * *}(-5.459)$ & $-0.571^{* * *}(-5.398)$ \\
\hline $\operatorname{prod}_{i t} \times D 0402 s$ & $0.244^{* * *}(7.139)$ & $0.238^{* * *}(6.992)$ \\
\hline $\operatorname{reer}_{i t} \times D 0402 s$ & $-0.687^{* * *}(-5.601)$ & $-0.610^{* * *}(-4.895)$ \\
\hline unemp $_{i t} \times D 0402 s$ & $0.262^{* *}(2.151)$ & $0.256^{* *}(2.113)$ \\
\hline
\end{tabular}

Dependent variable is $r_{-}$comp. Absolute t-values in parenthesis. All models are estimated with 2 factors, as suggested by PCA. The bandwidth was chosen using Silverman's rule of thumb. ${ }^{* *}$ : significant at $1 \%$, ** : at $5 \%$, *: at $10 \%$.

TABLE 8

Full long-run model - Structural break

Full Specification (1)

Full Specification (2) CUP - FM

$\operatorname{prod}_{i t}$

$-0.017$ CUP - BC CUP - FM

reer $_{\text {it }}$

$(-0.129)$

$-0.009$

CUP - BC

Selected Variables (1)

Selected Variables (2)

unemp $p_{i t}$

$0.267^{* * *}$

$(-0.768)$

$-0.150$

CUP - FM

$(-0.067)$

$(-1.055)$

0.013

CUP - BC

CUP - FM

(5.621)

$0.212^{* * *}$

$0.269^{* * *}$

$0.235^{* * *}$

(0.110)

$\begin{array}{ll}0.597^{* * *} & (4.367) \\ -0.754^{* * *} & -(5.112)\end{array}$

(5.798)

(4.962)

$0.232^{* * *}$

$-0.092$

0.010 CUP - BC

$E A_{i t}$

$(-4.976)$

$(-6.112)$

$-0.353^{* * *}$

$-0.540^{* * *}$

(4.962)

$(-0.655)$

(3.045)

$0.024^{* * *}$

$0.057^{* * *}$

$(-4.502)$

$-0.606^{* * *}$

(4.376)

$0.260^{* * *}$

$\begin{array}{ll}0.055^{* * *} & 0.024 \\ -0.023) & (2.764)\end{array}$

GOVIN $_{\text {it }}$

$-0.023^{* * *} \quad-0.024^{* * *}$

$T W E D_{i t}$

$(-4.886) \quad(-4.862)$

(6.902)

$-0.014^{* * *}$

$0.030^{* *}$

$(-5.033)$

$-0.750^{* * *}$

(5.706)

$0.243 * * *$

0.024

0.010

(3.154)

(3.579)

$0.053^{* * *}$

$(-6.060)$

$-0.350^{* * *}$

(5.223)

(2.425)

(1.623)

0.004

(4.266)

$-0.004$

(6.115)

$-0.022^{* * *}$

$0.024^{* * *}$

$(-3.000)$

$-0.530 * * *$

(2.736)

(6.952)

$0.030^{* * *}$

(0.252)

$(-0.238)$

$-0.024^{* * *}$

$-0.013^{* * *} \quad-0.020^{* * *}$

$(-2.952) \quad(-4.298)$ 


\begin{tabular}{|c|c|c|c|c|c|c|c|c|}
\hline$R I_{i t}$ & $\begin{array}{l}0.014^{* *} \\
(1.497)\end{array}$ & $\begin{array}{l}0.009 \\
(0.532)\end{array}$ & $\begin{array}{l}0.015^{* * *} \\
(2.636)\end{array}$ & $\begin{array}{l}0.009 \\
(1.529)\end{array}$ & $\begin{array}{l}0.015^{* *} \\
(2.522)\end{array}$ & $\begin{array}{l}0.010 \\
(1.644)\end{array}$ & $\begin{array}{l}0.015^{* * *} \\
(2.628)\end{array}$ & $\begin{array}{l}0.008 \\
(1.462)\end{array}$ \\
\hline$E P L_{i t}$ & $\begin{array}{l}0.001 \\
(0.596)\end{array}$ & $\begin{array}{l}0.009 \\
(0.424)\end{array}$ & $\begin{array}{l}0.003 \\
(1.266)\end{array}$ & $\begin{array}{l}0.001 \\
(0.672)\end{array}$ & & & & \\
\hline$W_{C O O R} i t$ & $\begin{array}{l}-0.010^{* *} \\
(-1.985)\end{array}$ & $\begin{array}{l}-0.011^{* *} \\
(-2.110)\end{array}$ & & & $\begin{array}{l}-0.010^{* *} \\
(-2.098)\end{array}$ & $\begin{array}{l}-0.010^{* *} \\
(-2.081)\end{array}$ & & \\
\hline$U D_{i t}$ & & & $\begin{array}{l}-0.212^{* * *} \\
(-5.993)\end{array}$ & $\begin{array}{l}-0.162^{* * *} \\
(-4.418)\end{array}$ & & & $\begin{array}{l}-0.211^{* * *} \\
(-5.946)\end{array}$ & $\begin{array}{l}-0.156^{* * *} \\
(-4.254)\end{array}$ \\
\hline$M W S_{i t}$ & $\begin{array}{l}0.003 \\
(1.240)\end{array}$ & $\begin{array}{l}0.003 \\
(1.476)\end{array}$ & $\begin{array}{l}0.004^{* *} \\
(2.340)\end{array}$ & $\begin{array}{l}0.005^{* * *} \\
(2.639)\end{array}$ & $\begin{array}{l}0.003 \\
(1.272)\end{array}$ & $\begin{array}{l}0.003 \\
(1.488)\end{array}$ & $\begin{array}{l}0.004^{* *} \\
(2.432)\end{array}$ & $\begin{array}{l}0.005^{* * *} \\
(2.689)\end{array}$ \\
\hline $\operatorname{prod}_{i t} \times D 0404 s$ & $\begin{array}{l}0.356^{* * *} \\
(8.691)\end{array}$ & $\begin{array}{l}0.440^{* * *} \\
(10.169)\end{array}$ & $\begin{array}{l}0.069 \\
(1.538)\end{array}$ & $\begin{array}{l}0.227^{* * *} \\
(4.892)\end{array}$ & $\begin{array}{l}0.360^{* * *} \\
(8.765)\end{array}$ & $\begin{array}{l}0.441^{* * *} \\
(10.181)\end{array}$ & $\begin{array}{l}0.071 \\
(1.585)\end{array}$ & $\begin{array}{l}0.235^{* * *} \\
(5.068)\end{array}$ \\
\hline reer $_{i t} \times D 0404 s$ & $\begin{array}{l}-0.499^{* * *} \\
(-4.348)\end{array}$ & $\begin{array}{l}-0.451^{* * *} \\
(-3.867)\end{array}$ & $\begin{array}{l}-0.325^{* * *} \\
(-2.914)\end{array}$ & $\begin{array}{l}-0.374^{* * *} \\
(-3.311)\end{array}$ & $\begin{array}{l}-0.447^{* * *} \\
(-3.894)\end{array}$ & $\begin{array}{l}-0.442^{* * *} \\
(-3.799)\end{array}$ & $\begin{array}{l}-0.302^{* * *} \\
(-2.711)\end{array}$ & $\begin{array}{l}-0.383^{* * *} \\
(-3.395)\end{array}$ \\
\hline unemp $_{i t} \times D 0404 s$ & $\begin{array}{l}0.198 \\
(1.428)\end{array}$ & $\begin{array}{l}0.312^{* *} \\
(2.201)\end{array}$ & $\begin{array}{l}0.137 \\
(1.049)\end{array}$ & $\begin{array}{l}0.261^{*} \\
(1.942)\end{array}$ & $\begin{array}{l}0.232 \\
(1.670)\end{array}$ & $\begin{array}{l}0.321^{* *} \\
(2.259)\end{array}$ & $\begin{array}{l}0.155 \\
(1.179)\end{array}$ & $\begin{array}{l}0.003^{* *} \\
(1.967)\end{array}$ \\
\hline$G_{O V I N} \times D 0404 s$ & $\begin{array}{l}0.030^{* * *} \\
(5.265)\end{array}$ & $\begin{array}{l}0.034^{* * *} \\
(5.764)\end{array}$ & $\begin{array}{l}0.018^{* * * *} \\
(3.331)\end{array}$ & $\begin{array}{l}0.027^{* * *} \\
(4.922)\end{array}$ & $\begin{array}{l}0.028^{* * *} \\
(4.954)\end{array}$ & $\begin{array}{l}0.033^{* * *} \\
(5.732)\end{array}$ & $\begin{array}{l}0.017^{* * *} \\
(3.112)\end{array}$ & $\begin{array}{l}0.027^{* * *} \\
(4.954)\end{array}$ \\
\hline$T W E D_{i t} \times D 0404 s$ & $\begin{array}{l}-0.177^{* * *} \\
(-7.473)\end{array}$ & $\begin{array}{l}-0.279^{* * *} \\
(-11.65)\end{array}$ & $\begin{array}{l}-0.119^{* * *} \\
(-5.225)\end{array}$ & $\begin{array}{l}-0.254^{* * *} \\
(-11.088)\end{array}$ & $\begin{array}{l}-0.168^{* * *} \\
(-7.127)\end{array}$ & $\begin{array}{l}-0.276^{* * *} \\
(-11.623)\end{array}$ & $\begin{array}{l}-0.109^{* * *} \\
(-4.806)\end{array}$ & $\begin{array}{l}-0.253^{* * *} \\
(-11.114)\end{array}$ \\
\hline$R I_{i t} \times D 0404 s$ & $\begin{array}{l}-0.042^{* * *} \\
(-5.308)\end{array}$ & $\begin{array}{l}0.041^{* * *} \\
(-5.211)\end{array}$ & $\begin{array}{l}-0.024^{* * *} \\
(-3.656)\end{array}$ & $\begin{array}{l}-0.025^{* * *} \\
(-3.737)\end{array}$ & $\begin{array}{l}-0.042^{* * *} \\
(-5.382)\end{array}$ & $\begin{array}{l}-0.042^{* * *} \\
(-5.261)\end{array}$ & $\begin{array}{l}-0.025^{* * *} \\
(-3.725)\end{array}$ & $\begin{array}{l}-0.026^{* * *} \\
(-3.813)\end{array}$ \\
\hline$E P L_{i t} \times D 0404 s$ & $\begin{array}{l}0.024^{* * *} \\
(5.913)\end{array}$ & $\begin{array}{l}0.020^{* * *} \\
(4.901)\end{array}$ & $\begin{array}{l}0.018^{* * *} \\
(4.474)\end{array}$ & $\begin{array}{l}0.015^{* * *} \\
(3.802)\end{array}$ & $\begin{array}{l}0.025^{* * *} \\
(6.292)\end{array}$ & $\begin{array}{l}0.021^{* * *} \\
(5.081)\end{array}$ & $\begin{array}{l}0.019 * * * \\
(4.869)\end{array}$ & $\begin{array}{l}0.016^{* * *} \\
(4.059)\end{array}$ \\
\hline$W C O O R_{i t} \times D 0404 s$ & $\begin{array}{l}0.013^{* *} \\
(2.312)\end{array}$ & $\begin{array}{l}0.014^{* *} \\
(2.560)\end{array}$ & & & $\begin{array}{l}0.014^{* *} \\
(2.418)\end{array}$ & $\begin{array}{l}0.014^{* *} \\
(2.535)\end{array}$ & & \\
\hline$U D_{i t} \times D 0404 s$ & & & $\begin{array}{l}0.182^{* * *} \\
(5.568)\end{array}$ & $\begin{array}{l}0.141^{* * *} \\
(4.164)\end{array}$ & & & $\begin{array}{l}0.182^{* * * *} \\
(5.566)\end{array}$ & $\begin{array}{l}0.136^{* * *} \\
(4.017)\end{array}$ \\
\hline$M W S_{i t} \times D 0404 s$ & $\begin{array}{l}0.006^{* * *} \\
(3.926)\end{array}$ & $\begin{array}{l}0.005^{* * *} \\
(3.093)\end{array}$ & $\begin{array}{l}0.012^{* * *} \\
(7.100)\end{array}$ & $\begin{array}{l}0.008^{* * *} \\
(4.653)\end{array}$ & $\begin{array}{l}0.006^{* * *} \\
(4.030)\end{array}$ & $\begin{array}{l}0.005^{* * *} \\
(3.040)\end{array}$ & $\begin{array}{l}0.012^{* * *} \\
(7.060)\end{array}$ & $\begin{array}{l}0.008^{* * *} \\
(4.486)\end{array}$ \\
\hline
\end{tabular}

Dependent variable is $r_{-}$comp. Absolute t-values in parenthesis. Models are estimated with 2 factors, as suggested by PCA. Bandwidth chosen using Silverman's rule of thumb. ***: significant at $1 \%,{ }^{* *}$ : at $5 \%$, ${ }^{*}$ : at $10 \%$. 
TABLE 9

Robustness Checks

Model with WCOOR

Model with UD

\begin{tabular}{|c|c|c|c|c|}
\hline & CUP - FM & CUP - BC & CUP - FM & CUP - BC \\
\hline $\operatorname{prod}_{i t}$ & $\begin{array}{l}-0.028 \\
(-0.216)\end{array}$ & $\begin{array}{l}-0.141 \\
(-0.991)\end{array}$ & $\begin{array}{l}-0.032 \\
(-0.243)\end{array}$ & $\begin{array}{l}-0.198 \\
(-1.352)\end{array}$ \\
\hline neer $_{i t}$ & $\begin{array}{l}-0.174 * * * \\
(-2.876)\end{array}$ & $\begin{array}{l}-0.140^{* * *} \\
(-2.271)\end{array}$ & $\begin{array}{l}-0.139 * * \\
(-2.324)\end{array}$ & $\begin{array}{l}-0.118^{*} \\
(-1.943)\end{array}$ \\
\hline unemp $_{i t}$ & $\begin{array}{l}-0.752^{* * *} \\
(-6.261)\end{array}$ & $\begin{array}{l}-0.836 * * * \\
(-6.766)\end{array}$ & $\begin{array}{l}-0.401^{* * *} \\
(-3.445)\end{array}$ & $\begin{array}{l}-0.569 * * * \\
(-4.730)\end{array}$ \\
\hline$E A_{i t}$ & $\begin{array}{l}0.033^{* * *} \\
(3.390)\end{array}$ & $\begin{array}{l}-0.001 \\
(-0.173)\end{array}$ & $\begin{array}{l}0.034^{* * *} \\
(4.226)\end{array}$ & $\begin{array}{l}0.006 \\
(0.689)\end{array}$ \\
\hline$G_{O V I N}$ & $\begin{array}{l}-0.020^{* * *} \\
(-4.325)\end{array}$ & $\begin{array}{l}-0.023^{* * *} \\
(-4.573)\end{array}$ & $\begin{array}{l}-0.016^{* * *} \\
(-3.538)\end{array}$ & $\begin{array}{l}-0.021^{* * *} \\
(-4.522)\end{array}$ \\
\hline$T W E D_{i t}$ & $\begin{array}{l}0.006 \\
(0.363)\end{array}$ & $\begin{array}{l}-0.002 \\
(-0.149)\end{array}$ & $\begin{array}{l}-0.020 \\
(-1.259)\end{array}$ & $\begin{array}{l}-0.021 \\
(-1.293)\end{array}$ \\
\hline$R I_{i t}$ & $\begin{array}{l}0.015^{* * * *} \\
(2.634)\end{array}$ & $\begin{array}{l}0.012^{*} \\
(1.934)\end{array}$ & $\begin{array}{l}0.015^{* *} \\
(2.711)\end{array}$ & $\begin{array}{l}0.010^{*} \\
(1.727)\end{array}$ \\
\hline$E P L_{i t}$ & $\begin{array}{l}0.001 \\
(0.634)\end{array}$ & $\begin{array}{l}0.001 \\
(0.506)\end{array}$ & $\begin{array}{l}0.003 \\
(1.303)\end{array}$ & $\begin{array}{l}0.002 \\
(0.730)\end{array}$ \\
\hline$W C O O R_{i t}$ & $\begin{array}{l}-0.021^{* * *} \\
(-4.302)\end{array}$ & $\begin{array}{l}-0.017^{* * *} \\
(-3.547)\end{array}$ & & \\
\hline$U D_{i t}$ & & & $\begin{array}{l}-0.232^{* * *} \\
(-6.539)\end{array}$ & $\begin{array}{l}-0.173 * * * \\
(-4.665)\end{array}$ \\
\hline$M W S_{i t}$ & $\begin{array}{l}0.003 \\
(1.451)\end{array}$ & $\begin{array}{l}0.004^{*} \\
(1.730)\end{array}$ & $\begin{array}{l}0.006^{* * *} \\
(3.463)\end{array}$ & $\begin{array}{l}0.007^{* * *} \\
(3.492)\end{array}$ \\
\hline $\operatorname{prod}_{i t} \times D 0404 s$ & $\begin{array}{l}0.349^{* * *} \\
(8.624)\end{array}$ & $\begin{array}{l}0.424^{* * *} \\
(9.907)\end{array}$ & $\begin{array}{l}0.036 \\
(0.803)\end{array}$ & $\begin{array}{l}0.208^{* * *} \\
(4.452)\end{array}$ \\
\hline neer $_{i t} \times D 0404 s$ & $\begin{array}{l}-0.738^{* * *} \\
(-5.144)\end{array}$ & $\begin{array}{l}-0.256^{*} \\
(-1.741)\end{array}$ & $\begin{array}{l}-0.644^{* * *} \\
(-4.589)\end{array}$ & $\begin{array}{l}-0.264^{*} \\
(-1.842)\end{array}$ \\
\hline$u_{n e m p} p_{i t} \times D 0404 s$ & $\begin{array}{l}0.396^{* * *} \\
(2.914)\end{array}$ & $\begin{array}{l}0.367 * * \\
(2.631)\end{array}$ & $\begin{array}{l}0.339 * * \\
(-2.607)\end{array}$ & $\begin{array}{l}0.358^{* *} \\
(2.670)\end{array}$ \\
\hline$G_{O V I N} \times D 0404 s$ & $\begin{array}{l}0.026^{* * *} \\
(4.479)\end{array}$ & $\begin{array}{l}0.032--- \\
(5.395)\end{array}$ & $\begin{array}{l}0.018^{* * *} \\
(-3.260)\end{array}$ & $\begin{array}{l}0.027^{* * * *} \\
(4.888)\end{array}$ \\
\hline$T W E D_{i t} \times D 0404 s$ & $\begin{array}{l}-0.182^{* * *} \\
(-7.551)\end{array}$ & $\begin{array}{l}-0.278^{* * *} \\
(-5.014)\end{array}$ & $\begin{array}{l}-0.135^{* * *} \\
(-5.793)\end{array}$ & $\begin{array}{l}-0.021^{* * *} \\
(-3.124)\end{array}$ \\
\hline$R I_{i t} \times D 0404 s$ & $\begin{array}{l}-0.040^{* * *} \\
(-5.032)\end{array}$ & $\begin{array}{l}-0.040^{* * *} \\
(-11.414)\end{array}$ & $\begin{array}{l}-0.017^{* *} \\
(-2.570)\end{array}$ & $\begin{array}{l}-0.270^{* * *} \\
(-11.456)\end{array}$ \\
\hline$E P L_{i t} \times D 0404 s$ & $\begin{array}{l}0.028^{* * *} \\
(6.814)\end{array}$ & $\begin{array}{l}0.022^{* * *} \\
(5.354)\end{array}$ & $\begin{array}{l}0.022^{* * *} \\
(5.482)\end{array}$ & $\begin{array}{l}0.018^{* * *} \\
(4.471)\end{array}$ \\
\hline$W C O O R_{i t} \times D 0404 s$ & $\begin{array}{l}0.019 * * * \\
(3.439)\end{array}$ & $\begin{array}{l}0.017^{* * *} \\
(3.029)\end{array}$ & & \\
\hline$U D_{i t} \times D 0404 s$ & & & $\begin{array}{l}0.188^{* * *} \\
(5.742)\end{array}$ & $\begin{array}{l}0.145^{* * *} \\
(4.269)\end{array}$ \\
\hline$M W S_{i t} \times D 0404 s$ & $\begin{array}{l}0.008^{* * *} \\
(4.820)\end{array}$ & $\begin{array}{l}0.006^{* * *} \\
(3.361)\end{array}$ & $\begin{array}{l}0.013^{* * *} \\
(7.405)\end{array}$ & $\begin{array}{l}0.008^{* * *} \\
(4.650)\end{array}$ \\
\hline
\end{tabular}

Note: Dependent variable is $r_{-}$comp. Absolute t-values in parenthesis. Models are estimated with 1 factor, as suggested by PCA. Bandwidth chosen using Silverman's rule of thumb. ${ }^{* * *}$ : significant at $1 \%,{ }^{* *}$ : at $5 \%,{ }^{*}$ : at $10 \%$. 


\section{FIGURE 1}

Real compensation per employee in EMU-12 countries, 1995-2011

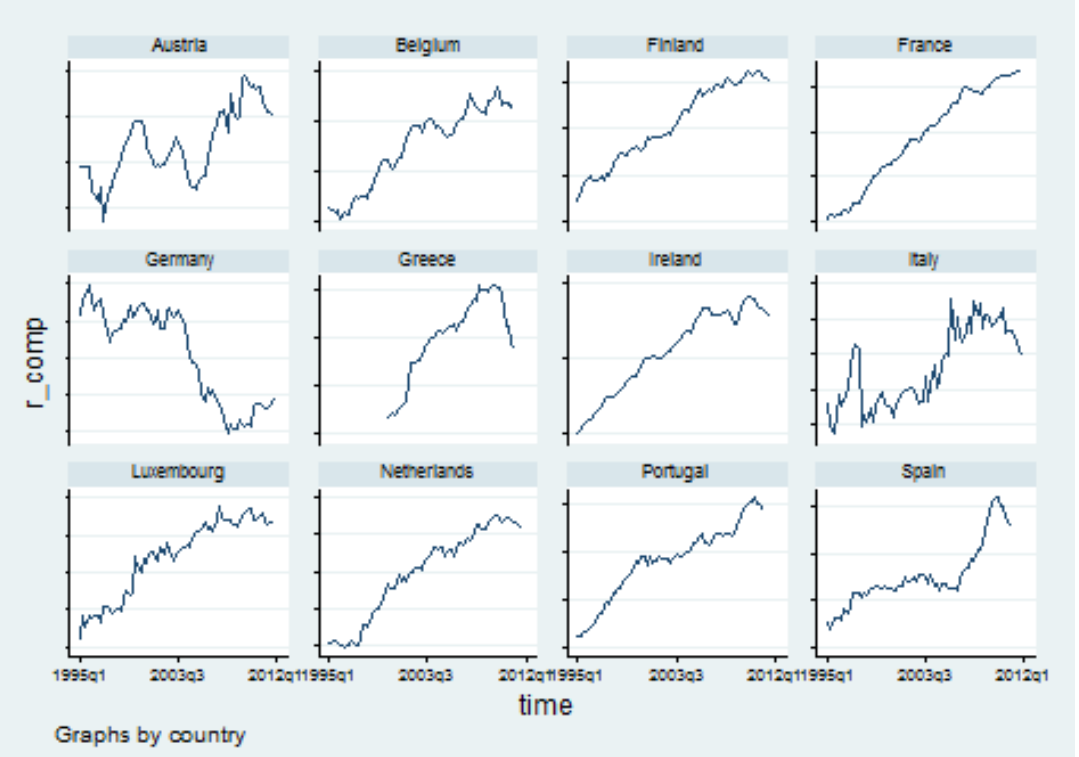

Source: Eurostat and authors' calculations.

FIGURE 2

The Relationship between bargaining coordination and the real wage

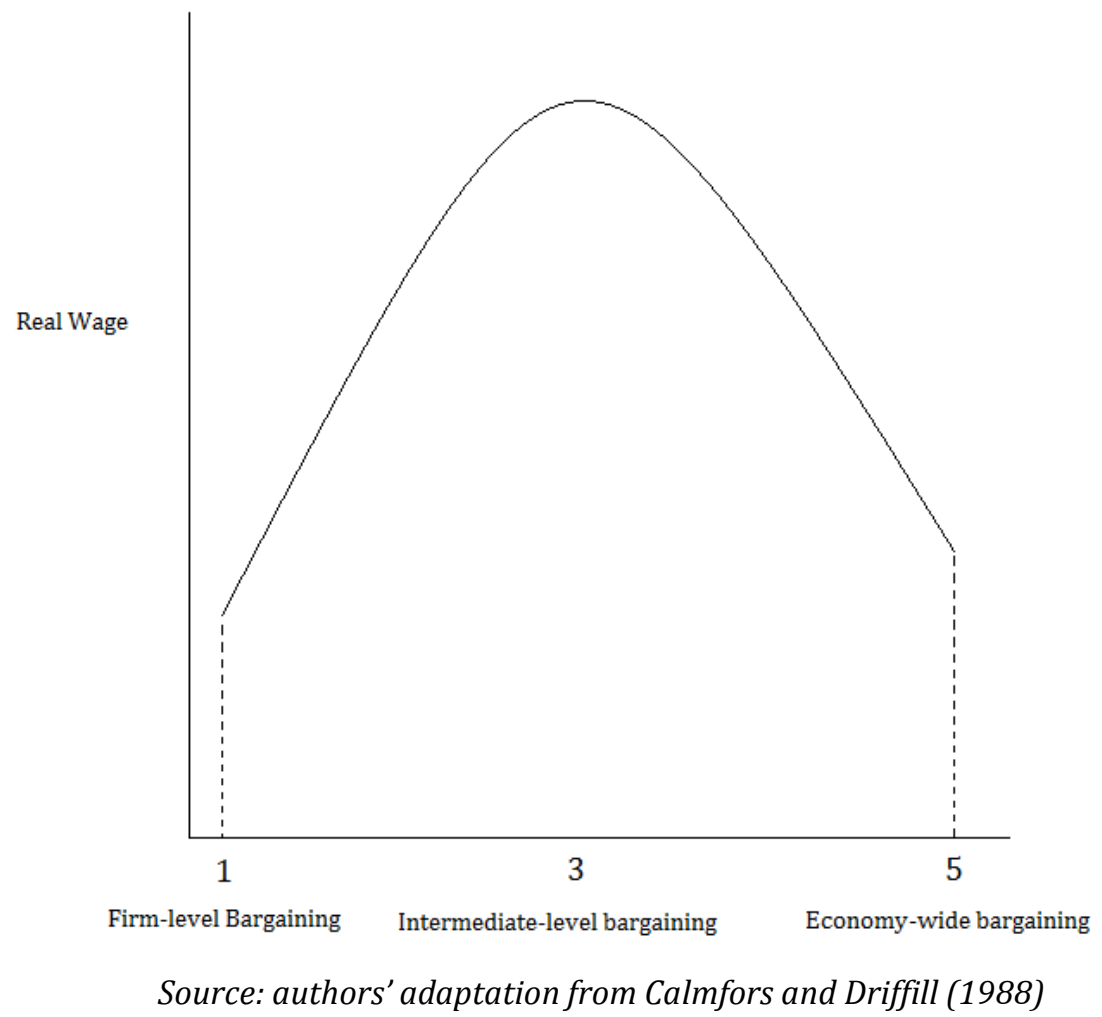


FIGURE 3

The degree of openness of EMU-11 countries

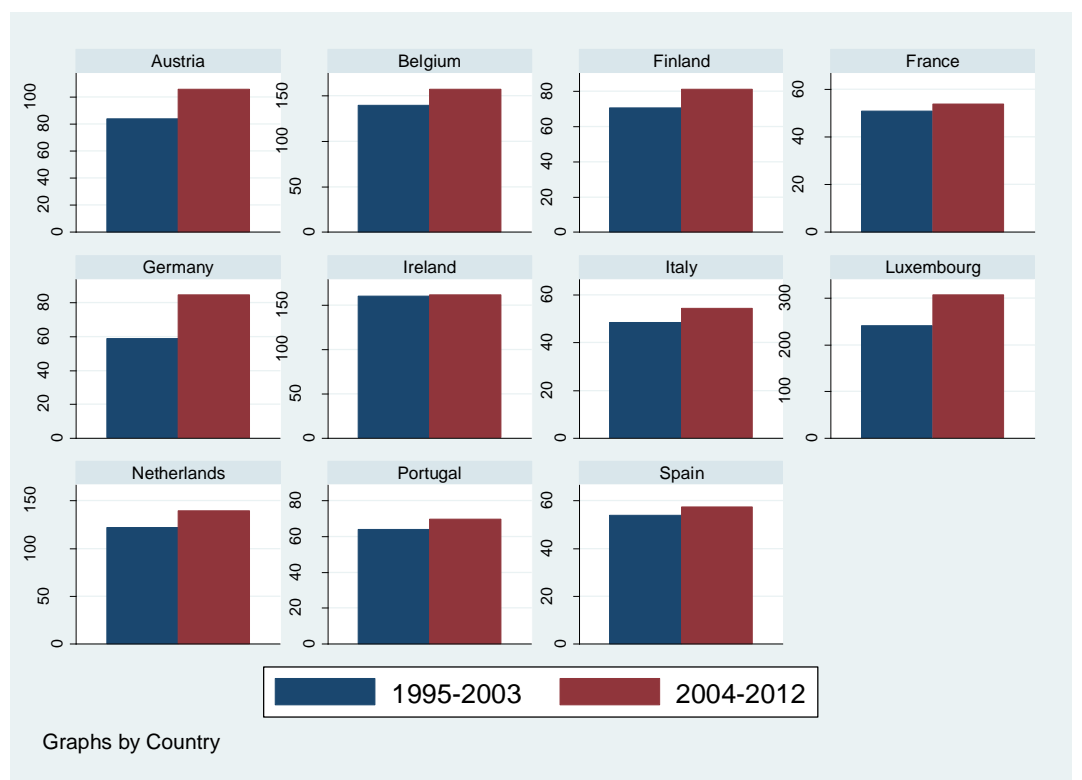

Source: Eurostat and authors' calculations. The Degree of openness is calculated as the sum of imports and exports of goods and services over GDP. 